\title{
Quantum-cascade lasers of mid-IR spectral range: epitaxy, diagnostics and device characteristics
}

\author{
A. V. Babichev ${ }^{1}$, A. G. Gladyshev ${ }^{2}$, E. S. Kolodeznyi ${ }^{1}$, A. S. Kurochkin ${ }^{1}$, \\ G. S. Sokolovskii ${ }^{3}$, V. E. Bougrov ${ }^{1}$, L. Ya. Karachinsky ${ }^{1,2,3}$, I. I. Novikov ${ }^{1,2,3}$, \\ V. V. Dudelev ${ }^{3}$, V. N. Nevedomsky ${ }^{3}$, S. O. Slipchenko ${ }^{3}$, A. V. Lutetskiy ${ }^{3}$, A. N. Sofronov ${ }^{4}$, \\ D.A. Firsov ${ }^{4}$, L.E. Vorobjev ${ }^{4}$, N. A. Pikhtin ${ }^{3}$, A. Bousseksou ${ }^{5}$, A. Yu. Egorov ${ }^{1}$ \\ ${ }^{1}$ ITMO University, St. Petersburg, Russia, a.babichev@ corp.ifmo.ru \\ ${ }^{2}$ Connector Optics LLC, St. Petersburg, Russia \\ ${ }^{3}$ Ioffe Institute, St. Petersburg, Russia \\ ${ }^{4}$ Peter the Great St. Petersburg Polytechnic University, St. Petersburg, Russia \\ ${ }^{5}$ Center of Nanoscience and Nanotechnology (C2N), Universit'e, Paris Sud and Paris-Saclay, Orsay cedex, France
}

Since the first practical realization of quantumcascade lasers (QCL) the considerable progress has been achieved in the theory, epitaxy, and laser formation. Growth of QCL lasers by metal-organic chemical vapour deposition instead of molecular beam epitaxy (MBE) has been demonstrated [1,2]. The using of MBE increases the efficiency of QCL mainly due to the possibility to grow high quality identical multiperiod superlattices. Smooth control of epitaxial growth rate during the growth of QCL heterostructures [3,4] and/or using of cell with increased stability of the fluxes of elements of Group III $[5,6]$ allow increasing the identity of QCL cascades. In this paper we report on epitaxy, diagnostics and device characteristics of QCL heterostructures grown using the industrial MBE system Riber 49 utilizing the ABI 1000 cells with a cylindrical crucible.

The first design (type 1) with the active region based on bound-to-continuum design $[7,8]$ was suggested for lasing at $\sim 6 \mu \mathrm{m}$. Before forming the stages of the laser on an InP substrate, an $100 \mathrm{~nm}$ $\mathrm{In}_{0.53} \mathrm{Ga}_{0.47} \mathrm{As}$ buffer layer doped by silicon ( $\mathrm{Si}$ ) and lattice matched to InP was grown. The heterostructure contains 60 stages formed by the strain-compensated $\mathrm{In}_{0.44} \mathrm{Al}_{0.56} \mathrm{As} / \mathrm{In}_{0.60} \mathrm{Ga}_{0.40} \mathrm{As}$ heteropair that provided the necessary elastic balance in the QCL stages and a band offset $\Delta \mathrm{E}_{\mathrm{c}}$ of more than $630 \mathrm{meV}$ at the heterointerface. The $\mathrm{In}_{0.52} \mathrm{Al}_{0.48} \mathrm{As}$ top cladding layer and $\mathrm{In}_{0.53} \mathrm{Ga}_{0.47} \mathrm{As}$ contact layer doped by $\mathrm{Si}$ have thickness of 1500 and $50 \mathrm{~nm}$, respectively.

The active region design with the escape of charge carriers due to two-phonon resonance was used for $8 \mu \mathrm{m}$ spectral range QCL heterostructure and consisted of 50 stages based on the $\mathrm{In}_{0.53} \mathrm{Ga}_{0.47} \mathrm{As} / \mathrm{Al}_{0.48} \mathrm{In}_{0.52} \mathrm{As}$ heteropair lattice matched to InP substrate. It was developed three waveguide types in $8 \mu \mathrm{m}$ spectral range QCL heterostructures. First of them (type 2A) consisted of bottom cladding based on InP $\left(2 \mu \mathrm{m}\right.$ thick) and $\operatorname{In}_{0.53} \mathrm{Ga}_{0.47} \mathrm{As}(0.5 \mu \mathrm{m}$ thick) layers, which were grown on a substrate in succession, the active region including 50 stages and $\mathrm{In}_{0.53} \mathrm{Ga}_{0.47} \mathrm{As}$ layers of top cladding with $1 \times 10^{17} \mathrm{~cm}^{-}$ 3 and $1 \times 10^{19} \mathrm{~cm}^{-3}$ doping levels and with thickness of $0.1 \mu \mathrm{m}$ and $0.02 \mu \mathrm{m}$, respectively $[9,10]$. Second of them (type 2B) was based on the bottom $\mathrm{In}_{0.53} \mathrm{Ga}_{0.47} \mathrm{As}$ waveguide layer $(0.5 \mu \mathrm{m}$ thick $)$, active region layers, top cladding layers based on InP $(0.75$ $\mu \mathrm{m}$ thick), waveguide based $\operatorname{In}_{0.53} \mathrm{Ga}_{0.47}$ As and contact
$\mathrm{In}_{0.53} \mathrm{Ga}_{0.47}$ As layers with $1 \times 10^{17} \mathrm{~cm}^{-3}$ and $1 \times 10^{19}$ $\mathrm{cm}^{-3}$ doping level with thicknesses of $0.1 \mu \mathrm{m}$ and 0.02 $\mu \mathrm{m}$, respectively. Third of them (type $2 \mathrm{C}$ ) consisted of bottom $\operatorname{In}_{0.53} \mathrm{Ga}_{0.47} \mathrm{As}$ waveguide layer $(0.5 \mu \mathrm{m}$ thick), active region layers, top cladding layers based on InP (3.9 $\mu \mathrm{m}$ thick) and waveguide based on $\operatorname{In}_{0.53} \mathrm{Ga}_{0.47} \mathrm{As}$ and contact $\mathrm{In}_{0.53} \mathrm{Ga}_{0.47} \mathrm{As}$ layers with $1 \times 10^{17} \mathrm{~cm}^{-3}$ and $1 \times 10^{19} \mathrm{~cm}^{-3}$ doping level with thicknesses of 0.1 $\mu \mathrm{m}$ and $0.02 \mu \mathrm{m}$, respectively.

The three-phonon resonance design [5] was used for $9 \mu \mathrm{m}$ spectral range QCL heterostructure (type 3) and consisted of 40 periods based on $\operatorname{In}_{0.53} \mathrm{Ga}_{0.47} \mathrm{As}$ quantum wells with $\mathrm{Al}_{0.48} \operatorname{In}_{0.52} \mathrm{As}$ barrier layers. Heterostructure consisted of $\mathrm{In}_{0.53} \mathrm{Ga}_{0.47} \mathrm{As}$ : $\mathrm{Si}$ (with $1 \times$ $10^{18} \mathrm{~cm}^{-3}$ doping level) current spreading layer with a thickness of $50 \mathrm{~nm}$, bottom cladding $\mathrm{In}_{0.53} \mathrm{Ga}_{0.47} \mathrm{As}$ : $\mathrm{Si}$ layer with $5 \times 10^{16} \mathrm{~cm}^{-3}$ doping level and $4 \mu \mathrm{m}$ thick active region layers, top cladding layers ( $4 \mu \mathrm{m}$ thick) based on step-doped $\mathrm{Al}_{0.48} \mathrm{In}_{0.52} \mathrm{As}: \mathrm{Si}\left(1 \times 10^{17} / 1 \times\right.$ $\left.10^{18} \mathrm{~cm}^{-3}\right)$ and $0.2 \mu \mathrm{m}$ thick contact layer of $\mathrm{In}_{0.53} \mathrm{Ga}_{0.47} \mathrm{As}$ : Si $\left(5 \times 10^{18} \mathrm{~cm}^{-3}\right)$.

The heterostructure of the dual-frequency QCL (type 4) consisted of $\mathrm{In}_{0.53} \mathrm{Ga}_{0.47} \mathrm{As}$ : $\mathrm{Si}$ (with $1 \times 10^{18}$ $\mathrm{cm}^{-3}$ doping level) current spreading layer with a thickness of $50 \mathrm{~nm}$, bottom cladding $\operatorname{In}_{0.53} \mathrm{Ga}_{0.47} \mathrm{As}: \mathrm{Si}$ layer with $5 \times 10^{16} \mathrm{~cm}^{-3}$ doping level $(2.1 \mu \mathrm{m}$ thick), sequence of 15 stages of type 2 active region, sequence of 36 stages of type 3 active region, sequence of 15 stages of type 2 active region, top cladding layers based on $\operatorname{In}_{0.53} \mathrm{Ga}_{0.47} \mathrm{As}(1.95 \mu \mathrm{m}$ thick) and $\mathrm{In}_{0.52} \mathrm{Al}_{0.48} \mathrm{As}(2 \mu \mathrm{m}$ thick $)$ and $0.02 \mu \mathrm{m}$ thick contact layer of $\operatorname{In}_{0.53} \mathrm{Ga}_{0.47} \mathrm{As}$ : Si with $1 \times 10^{19} \mathrm{~cm}^{-3}$ doping level.

X-ray diffraction measurements showed narrow satellite peaks, which indicate high structural perfection of the multi-stage QCL heterostructures. The spectra of X-ray diffraction were measured with high resolution in the vicinity of the InP symmetrical (004) reflection using a PANanalytical X'PertPro diffractometer with parallel geometry of the X-ray radiation beam. Additional analysis of high-resolution transmission electron microscopy (TEM) proved the absent of extended defects and that all layers have planar heteroboundaries. The TEM studies were conducted at a JEM2100F transmission electron microscope with an accelerating voltage of $200 \mathrm{keV}$.

The heterostructures of QCL were processed in four-cleaved and ridge geometries and mounted on 
copper heatsink using the indium solder to study the spontaneous and stimulated emission.

The QCL of type 1 based on strained heteropair $\mathrm{In}_{0.44} \mathrm{Al}_{0.56} \mathrm{As} / \mathrm{In}_{0.60} \mathrm{Ga}_{0.40} \mathrm{As}$ with $\mathrm{Al}_{0.48} \mathrm{In}_{0.52} \mathrm{As}$ top cladding has shown the room-temperature lasing at threshold current density of $4.8 \mathrm{kA} / \mathrm{cm}^{2}$ with the peak emission wavelength about $5.8 \mu \mathrm{m}$ [3]. The estimated output optical power from one facet was about 150 $\mathrm{mW}$ in pulse mode.

The QCL of type 2A (waveguide with air cladding) demonstrated the lasing at room temperature with the threshold current density about $5.1 \mathrm{kA} / \mathrm{cm}^{2}$ [9]. The lasing spectra demonstrate maximum close to $8 \mu \mathrm{m}$. The same QCL with full top metallization demonstrate the lasing up to $250 \mathrm{~K}$ with the threshold current density about $5 \mathrm{kA} / \mathrm{cm}^{2}$ [11].

The QCL of type 2B (waveguide with thin top cladding) demonstrated the lasing at room temperature and the threshold current density about $5.6 \mathrm{kA} / \mathrm{cm}^{2}$. The lasing wavelength was close to 7.8 $\mu \mathrm{m}$. The estimated output peak optical power measured at $300 \mathrm{~K}$ was about $100 \mathrm{~mW}$.

The QCL of type $2 \mathrm{C}$ (waveguide with thick top cladding) demonstrated the lasing at room temperature with wavelength $8.0 \mu \mathrm{m}$ and the threshold current density about $4.9 \mathrm{kA} / \mathrm{cm}^{2}$. The estimated output peak optical power measured at $300 \mathrm{~K}$ was about $200 \mathrm{~mW}$.

For type 3 QCL the lasing up to $140 \mathrm{~K}$ was demonstrated. Threshold current density determined at $87 \mathrm{~K}$ was about $3 \mathrm{kA} / \mathrm{cm}^{2}$. The estimated output optical power is about $20-35 \mathrm{~mW}$, measured from one facet in pulse mode [5].

The heterostructure of dual-frequency QCL based on type 3 design was created and its structural and optical quality was studied. The design of waveguide with uniform pumping of both active regions [12] was implemented in this heterostructure. The realization of waveguide based on 2 active region one emitting at $7.6 \mu \mathrm{m}$ wavelength and separated by other active region emitting at wavelengths of $9.6 \mu \mathrm{m}$ allows to reach the lasing close to $7.6 \mu \mathrm{m}$ and well pronounce of spontaneous emission near $9.6 \mu \mathrm{m}$.

To summarize, we presented the results of the study of QCL with different active region inside 5-10 $\mu \mathrm{m}$ spectral range. Room temperature lasing with output optical power about a few hundreds of milliwatt was demonstrated. The further optimization should be related with usage of thick InP top cladding and decreasing of injector doping level aimed to reach low threshold current density that is necessary for the high-power continuous-wave lasing.

This was supported by the Ministry of Education and Science of the Russian Federation within the Federal target program "Research and Development in Priority Areas of the Science and Technology Complex of Russia for 2014-2020", code no. 2016-14579-0009, unique identifier RFMEFI57816X0204.

\section{References}

1. Wang, C. A., Schwarz, B., Siriani, D. F., Missaggia, L. J., Connors, M. K., Mansuripur, T. S., Calawa, D. R., McNulty, D., Nickerson, M., Donnelly, J. P., Creedon, K.
MOVPE growth of LWIR AlInAs/GaInAs/InP quantum cascade lasers: Impact of growth and material quality on laser performance // IEEE J. Sel. Top. Quantum Electron. 2017. V. 23, No. 6. P. 1-13.

2. Zasavitskii, I. I., Kovbasa, N. Y., Raspopov, N. A., Lobintsov, A. V., Kurnyavko, Y. V., Gorlachuk, P. V., Krysa A.B., Revin, D. G. // A GaInAs/AlInAs quantum cascade laser with an emission wavelength of $5.6 \mu \mathrm{m} / /$ Quantum Electron. 2018. V. 48, No. 5. P. 472-475.

3. Babichev, A. V., Bousseksou, A., Pikhtin, N. A., Tarasov, I. S., Nikitina, E. V., Sofronov, A. N., Firsov D. A., Vorobjev L. E., Novikov I. I., Karachinsky L. Y., Egorov, A. $Y$. Room-temperature operation of quantum cascade lasers at a wavelength of $5.8 \mu \mathrm{m} / /$ Semiconductors 2016. V. 50, No. 10. P. 1299-1303.

4. Mamutin, V. V., Vasilyev, A. P., Lyutetskiy, A. V., Ilyinskaya, N. D., Zadiranov, Y. M., Sofronov, A. N., Firsov, D. A., Vorobjev, L. E., Maleev, N. A., Ustinov, V. M. On the Fabrication and Study of Lattice-Matched Heterostructures for Quantum Cascade Lasers // Semiconductors 2018. V. 52, No. 7. P. 950-953.

5. Babichev, A. V., Gusev, G. A., Sofronov, A. N., Firsov, D. A., Vorobjev, L. E., Usikova, A. A., Zadiranov, Yu. M., Il'inskaya, N. D., Nevedomsky, V. N., Dudelev, V. V., Sokolovskii, G. S., Gladyshev, A. G., Karachinsky, L. Ya., Novikov, I. I., Egorov A. Yu. Lasing of quantum-cascade laser at $9.6 \mu \mathrm{m}$ wavelength // Tech. Phys. 2018. V. 88, No. 10 , in press.

6. Babichev, A. V., Gladyshev, A. G., Filimonov, A. V., Nevedomskii, V. N., Kurochkin, A. S., Kolodeznyi, E. S., Sokolovskii, G. S., Bugrov, V. E., Karachinsky, L. Ya., Novikov, I. I., Bousseksou, A., Egorov, A. Yu. Heterostructures for quantum-cascade lasers of the wavelength range of 7-8 $\mu \mathrm{m} / /$ Tech. Phys. Lett. 2017. V. 43, No. 7. P. 666-669.

7. Faist, J., Beck, M., Aellen, T., Gini, E. Quantumcascade lasers based on a bound-to-continuum transition // Appl. Phys. Lett. 2001. V. 78, No. 2. P. 147-149.

8. Egorov, A. Y., Babichev, A. V., Karachinsky, L. Y., Novikov, I. I., Nikitina, E. V., Tchernycheva, M., Tchernycheva, M., Sofronov, A. N., Firsov, D. A., Vorobjev, L. E., Pikhtin, N. A., Tarasov, I. S. Lasing of multiperiod quantum-cascade lasers in the spectral range of (5.6-5.8)$\mu \mathrm{m}$ under current pumping // Semiconductors 2015. V. 49, No. 11. P. 1527-1530.

9. Babichev, A. V., Gladyshev, A. G., Kurochkin, A. S., Kolodeznyi, E. S., Sokolovskii, G. S., Bougrov, V. E., Karachinsky L. Ya., Novikov I. I., Bousseksou A., Egorov, A. $Y$. Room Temperature Lasing of Multi-Stage QuantumCascade Lasers at $8 \mu \mathrm{m}$ Wavelength // Semiconductors 2018. V. 52, No. 8. P. 1082-1085.

10. Babichev, A. V., Gladyshev, A. G., Filimonov, A. V., Nevedomskii, V. N., Kurochkin, A. S., Kolodeznyi, E. S., Sokolovskii, G. S., Bugrov, V. E., Karachinsky, L. Ya., Novikov, I. I., Bousseksou, A., Egorov, A. Y. Heterostructures for quantum-cascade lasers of the wavelength range of 7-8 $\mu \mathrm{m} / /$ Tech. Phys. Lett. 2017. V. 43, No. 7. P. 666669.

11. Kurochkin, A. S., Babichev, A. V., Denisov, D. V., Karachinsky, L. Y., Novikov, I. I., Sofronov, A. N., Firsov, D. A., Vorobjev, L. E., Bousseksou, A., Egorov, A. $Y u$. Quantum-cascade lasers in the 7-8 $\mu \mathrm{m}$ spectral range with full top metallization // J. Phys.: Conf. Ser. 2018. V. 993, No. 1. P. 012031.

12. Babichev, A. V., Kurochkin, A. S., Kolodeznyi, E. C., Filimonov, A. V., Usikova, A. A., Nevedomsky, V. N., Gladyshev, A. G., Karachinsky, L. Ya., Novikov, I. I., Egorov, A. Yu. Heterostructures of SingleWavelength and Dual-Wavelength Quantum-Cascade Lasers // Semiconductors. 2018. V. 52, No. 6. P. 745-749. 